\title{
A novel approach in the treatment of neuroendocrine gastrointestinal tumors: Additive antiproliferative effects of interferon- $\gamma$ and meta-iodobenzylguanidine Michael Höpfner ${ }^{1}$, Andreas P Sutter ${ }^{1}$, Alexander Huether ${ }^{1}$, Gudrun Ahnert- Hilger $^{2}$ and Hans Scherübl*1
}

Address: ${ }^{1}$ Charité - Universitätsmedizin Berlin, Campus Benjamin Franklin, Medical Clinic I, Hindenburgdamm 30, 12200 Berlin, Germany and ${ }^{2}$ Charité - Universitätsmedizin Berlin, Campus Mitte, Institut für Anatomie, Philippstrasse 12, 10115 Berlin, Germany

Email: Michael Höpfner - michael.hoepfner@charite.de; Andreas P Sutter - andreas.sutter@charite.de; Alexander Huether - alexander.huether@charite.de; Gudrun Ahnert-Hilger - gudrun.ahnert@charite.de; Hans Scherübl* - hans.scherubl@charite.de

* Corresponding author

Published: 21 May 2004

BMC Cancer 2004, 4:23
Received: 22 December 2003

Accepted: 21 May 2004

This article is available from: http://www.biomedcentral.com/I47I-2407/4/23

(C) 2004 Höpfner et al; licensee BioMed Central Ltd. This is an Open Access article: verbatim copying and redistribution of this article are permitted in all media for any purpose, provided this notice is preserved along with the article's original URL.

\begin{abstract}
Background: Therapeutic options to effectively inhibit growth and spread of neuroendocrine gastrointestinal tumors are still limited. As both meta-iodobenzylguanidine (MIBG) and interferon$\gamma(\mathrm{IFN} \gamma)$ cause antineoplastic effects in neuroendocrine gastrointestinal tumor cells, we investigated the antiproliferative effects of the combination of IFN $\gamma$ and non-radiolabeled MIBG in neuroendocrine gut STC-I and pancreatic carcinoid BON tumor cells.
\end{abstract}

Methods and results: IFN $\gamma$ receptors were expressed in both models. IFN $\gamma$ dose- and timedependently inhibited the growth of both STC-I and of BON tumor cells with $I_{50}$-values of $95 \pm$ $15 \mathrm{U} / \mathrm{ml}$ and $135 \pm 10 \mathrm{U} / \mathrm{ml}$, respectively. Above $10 \mathrm{U} / \mathrm{ml} \mathrm{IFN} \gamma$ induced apoptosis-specific caspase3 activity in a time-dependent manner in either cell line and caused a dose-dependent arrest in the $\mathrm{S}$-phase of the cell cycle. Furthermore, IFN $\gamma$ induced cytotoxic effects in NE tumor cells.

The NE tumor-targeted drug MIBG is selectively taken up via norepinephrine transporters, thereby specifically inhibiting growth in NE tumor cells. Intriguingly, IFN $\gamma$ treatment induced an upregulation of norepinephrine transporter expression in neuroendocrine tumors cells, as determined by semiquantitative RT-PCR. Co-application of sub-I $\mathrm{C}_{50}$ concentrations of IFN $\gamma$ and MIBG led to additive growth inhibitory effects, which were mainly due to increased cytotoxicity and S-phase arrest of the cell cycle.

Conclusion: Our data show that IFN $\gamma$ exerts antiproliferative effects on neuroendocrine gastrointestinal tumor cells by inducing cell cycle arrest, apoptosis and cytotoxicity. The combination of IFN $\gamma$ with the NE tumor-targeted agent MIBG leads to effective growth control at reduced doses of either drug. Thus, the administration of IFN $\gamma$ alone and more so, in combination with MIBG, is a promising novel approach in the treatment of neuroendocrine gastrointestinal tumors. 


\section{Background}

Gastrointestinal neuroendocrine (NE) tumors represent a rare and rather heterogeneous tumor entity. Almost half of the metastatic NE gastrointestinal tumors release excessive amounts of biogenic amines and/or neuropeptides thereby causing a characteristic hypersecretion syndrome. The often bizarre clinical symptoms are generally well controlled by somatostatin analogues or interferon- $\alpha$ (IFN $\alpha)[1,2]$. However, further growth and spread is generally not prevented on the long by either biotherapy or conventional chemotherapy. Thus, innovative treatment strategies should be developed that are both effective and well tolerated.

A promising approach for novel treatment of NE gastrointestinal tumor disease may be the modulation of the IFN $\gamma$ receptor system. The immunomodulatory lymphokine IFN $\gamma$ modulates biological responses by binding to its cognate receptor thereby activating members of a transcription factor family termed STAT (signal transducers and activators of transcription) [3]. IFN $\gamma$-induced STAT signaling and STAT-associated induction of interferon regulatory factors (IRFs) have been shown to exert key regulatory function for proliferation, differentiation and survival [4]. The underlying mechanisms of IFN $\gamma$-induced growth inhibition show a broad spectrum, including the induction of cell cycle arrest, apoptosis and cytotoxcicity $[5,6]$.

Although interferons are known to evoke growth regulatory effects in many tissues, the effectiveness of IFNinduced growth inhibition varies between the various cell types. Thus, growth control observed in a given cell type does not allow to predict similar effects of IFN $\gamma$ on tissues of other origin [7].

IFN $\gamma$-induced growth inhibition in NE gastrointestinal tumors has not yet been evaluated in great detail. Here we examine the antineoplastic potency of IFN $\gamma$ alone or in combination with non-radiolabeled MIBG in NE gastrointestinal tumor cells of the gut and pancreas.

In its radiolabeled form the norepinephrine analog MIBG is an established diagnostic and therapeutic agent in neuroendocrine tumors expressing plasma membrane bound norepinephrine transporters [8-10]. Recently, we and others could show that even its non-radiolabeled form, the so-called "cold MIBG" can effectively inhibit the growth of neuroendocrine tumor cells $[11,12]$. Since IFN $\gamma$ has been reported to upregulate the MIBG-transporting norepinephrine transporter in neuroblastoma cells [13], it was intriguing to evaluate, whether this also held true for NE gastrointestinal tumors cells and whether such an upregulation could boost the antineoplastic potency of cold MIBG in NE tumor cells.

\section{Methods \\ Cell lines}

Human pancreatic carcinoid BON cells [14,15] were maintained in a 1:1 mixture of DMEM, and F12K medium containing 10\% FCS (Biochrom, Berlin, Germany) and 1\% L-glutamine. The murine intestinal neuroendocrine tumor cell line STC-1, which was a gift from Dr. D. Hanahan (University of California, San Francisco, CA), was maintained in DMEM supplemented with 15\% horse serum (Biochrom, Berlin, Germany), 2.5\% FCS (Biochrom) and 1\% L-glutamine [16]. The neuroendocrinedifferentiated human colorectal cancer cell line Colo 320 DM [17] was maintained in standard RPMI 1640 medium, complemented with 10\% FCS. All cell lines were kept at $37^{\circ} \mathrm{C}$ in a humidified atmosphere $\left(5 \% \mathrm{CO}_{2}\right)$.

\section{Drugs}

IFN $\gamma$ and non-radiolabeled meta-iodobenzylguanidine (MIBG) were purchased from Sigma (München, Germany). Stock solutions were prepared in water or DMSO, respectively, and stored at $-20^{\circ} \mathrm{C}$. The drugs were diluted in fresh media before each experiment. In all experiments, the final DMSO concentration was $<0.5 \%$. To evaluate the effects of IFN $\gamma$ and/or MIBG, cells were incubated with either control medium or medium containing rising concentrations of the respective drugs. Media were changed daily to ensure constant drug concentrations in the incubation medium.

\section{RT-PCR}

Semi-quantitative analysis of mRNA expression of the human plasma membrane bound norepinephrine transporter (hNET) and the housekeeping gene $\beta$-actin was carried out by RT-PCR with the number of cycles at which the band intensity increased linearly with the amount of mRNA used [18].

Total RNA was extracted from cultured cell lines with RNAClean following the recommendation of the manufacturer (Hybaid, London, UK). Reverse transcription and PCR reactions were carried out as described elsewhere in detail [19]. To eliminate any possible contamination with genomic DNA, RNAs were treated with 1 U DNAse I (Gibco, Karlsruhe, Germany) per $\mu \mathrm{g}$ RNA for $15 \mathrm{~min}$ at room temperature. Purified RNA was reverse transcribed into cDNA using oligo-dT-primers and the SuperScript Preamplification-Kit (Gibco). PCR reactions were carried out in a total volume of $50 \mu \mathrm{l}$ containing $400 \mathrm{nM}$ of each primer, $200 \mu \mathrm{M}$ of each dNTP (Pharmacia, Uppsala, Sweden), $50 \mathrm{mM} \mathrm{KCl}, 1.5 \mathrm{mM} \mathrm{MgCl}, 10 \mathrm{mM}$ Tris and $1 \mathrm{U}$ Taq-Polymerase (Pharmacia). PCR was performed in a Peltier thermocycler (PTC-200, MJ Research, Watertown, $\mathrm{MA}$ ) with primers and at the conditions indicated in table 1. 
Table I: Primer sequences and PCR conditions used to evaluate the expression of the transcripts indicated

\begin{tabular}{|c|c|c|c|c|c|c|}
\hline Genes & Primers $\left(5^{\prime}-3^{\prime}\right)$ & $\begin{array}{l}\text { Product } \\
\text { size (bp) }\end{array}$ & $\begin{array}{c}\text { Denaturing temperature } \\
\text { and time }(s)\end{array}$ & $\begin{array}{l}\text { Annealing temperature } \\
\text { and time (s) }\end{array}$ & $\begin{array}{l}\text { Extension temperature } \\
\text { and time }(s)\end{array}$ & $\begin{array}{l}\text { number } \\
\text { of cycles }\end{array}$ \\
\hline IFN $\gamma \mathrm{R}$ & $\begin{array}{l}\text { F:ACgCAgAAggAAgATgATTgTgACg } \\
\text { R:TCTATTggAgTCAgATggCTgCCC }\end{array}$ & 590 & $94^{\circ} \mathrm{C}(30)$ & $63^{\circ} \mathrm{C}(90)$ & $72^{\circ} \mathrm{C}(90)$ & 32 \\
\hline hNET & $\begin{array}{l}\text { F:CTggTggTgAAggAgCgCAACggC } \\
\text { R:ATgTgATgAATCCCgCTgCTCTCg }\end{array}$ & 241 & $94^{\circ} \mathrm{C}(60)$ & $63^{\circ} \mathrm{C}(60)$ & $72^{\circ} \mathrm{C}(60)$ & 32 \\
\hline$\beta$-actin & $\begin{array}{l}\text { F:ATCATgTTTgAgACCTTCAACAC } \\
\text { R:TCTgCgCAAgTTAggTTTTgTC }\end{array}$ & 822 & $94^{\circ} \mathrm{C}(60)$ & $63^{\circ} \mathrm{C}(60)$ & $72^{\circ} \mathrm{C}(60)$ & 32 \\
\hline
\end{tabular}

All templates were initially denaturated for $5 \mathrm{~min}$ at $95^{\circ} \mathrm{C}$ and the amplification was followed by a final extension temperature of $72^{\circ} \mathrm{C}$ for 7 min.

\section{Measurement of growth inhibition}

Changes in cell number of BON and STC-1 cells were determined by crystal violet staining after incubation with rising drug concentrations (IFN $\gamma$ : 0-500 U/ml; MIBG: 0$100 \mu \mathrm{M}$ ) for up to 5 days. Measurements were performed as described [20]. Cells were washed with PBS and fixed with $1 \%$ glutaraldehyde. After another washing step, cells were stained with $0.1 \%$ crystal violet. The unbound dye was removed by washing. Crystal violet that had absorbed onto the cells was solubilized with $0.2 \%$ Triton X-100. Then light extinction was analyzed at $570 \mathrm{~nm}$ using an ELISA reader.

\section{Cell cycle analysis}

Cell cycle analysis was performed by the method of Vindelov and Christensen, as described previously [21]. Cells were trypsinized, washed, and the nuclei were isolated using CycleTest PLUS DNA Reagent Kit (Becton Dickinson, Heidelberg, Germany). DNA was stained with propidium iodide according to the manufacturers' instructions. The DNA content of the nuclei was detected by flow cytometry and analyzed using CellFit software (Becton Dickinson, Heidelberg, Germany).

\section{Caspase-3 activity assay}

To determine apoptosis the activity of caspase-3, a key enzyme in the apoptotic cascade was measured. Preparation of cell lysates and determination of caspase- 3 activity was performed as described previously [22]. The activity of caspase- 3 was calculated from the cleavage of the fluorogenic substrate DEVD-AMC (Calbiochem-Novabiochem, Bad Soden, Germany). Cell lysates were incubated with substrate solution (caspase-3 substrate AC-DEVDAMC $20 \mu \mathrm{g} / \mathrm{ml}$, HEPES $20 \mathrm{mM}$, glycerol 10\%, DTT $2 \mathrm{mM}$, $\mathrm{pH} 7.5$ ) for $1 \mathrm{~h}$ at $37^{\circ} \mathrm{C}$, and the cleavage of DEVD-AMC was measured fluorometrically with a VersaFluor fluorometer (excitation: $360 \mathrm{~nm}$ emission: $460 \mathrm{~nm}$ ) from Biorad, Munich, Germany.

\section{Determination of cytotoxicity}

Cells were seeded at a density of 5,000 cells/well into 96well microtiter plates and incubated with IFN $\gamma(0-500 \mathrm{U} /$ $\mathrm{ml})$ or MIBG $(0-50 \mu \mathrm{M})$ or the combination of both. Release of the cytoplasmic enzyme lactate dehydrogenase (LDH), indicating cytotoxicity, was measured after $48 \mathrm{~h}$ of incubation by using the colorimetric kit from Roche as described elsewhere [20,23]. Background release obtained by measuring LDH release of untreated cells was subtracted. Maximum release of LDH was obtained by adding $100 \mu \mathrm{l}$ of $2 \%$ Triton X-100 to untreated cells. For determinations, $100 \mu \mathrm{l}$ of each sample were transferred to a 96well microtiter plate; $100 \mu \mathrm{l}$ of LDH assay reagent were added to each well and incubated for $30 \mathrm{~min}$ at room temperature in the dark. The absorbance of samples was then measured at $490 \mathrm{~nm}$. No significant LDH release was detected in the tissue culture medium alone nor in drugcontaining incubation medium.

\section{Statistical analysis}

The antineoplastic effects of the various substances and vehicles were compared by the unpaired, two-tailed Mann-Whitney U-test. The unpaired student t-test was used for cell cycle analysis. $P$ values were considered to be significant at $<0.05$. If not stated otherwise, all functional experiments were performed in quadruplicate.

\section{Results \\ Expression of IFN $\gamma$ receptors in NE gastrointestinal tumor cells}

To monitor IFN $\gamma$ receptors (IFN $\gamma \mathrm{R}$ ) in human pancreatic carcinoid BON cells, mRNA expression of IFN $\gamma \mathrm{R}$ was evaluated by RT-PCR. Using specific primers directed against the $\alpha$-chain of the human IFN $\gamma \mathrm{R}$ [24], we detected a robust expression of PCR-amplificates of the expected size (Fig. 1). The neuroendocrine-differentiated colorectal carcinoma cell line Colo320 DM served as a positive control. IFN $\gamma \mathrm{R}$ expression in murine intestinal NE STC-1 tumor cells has already been demonstrated by cDNA array analysis [11]. 


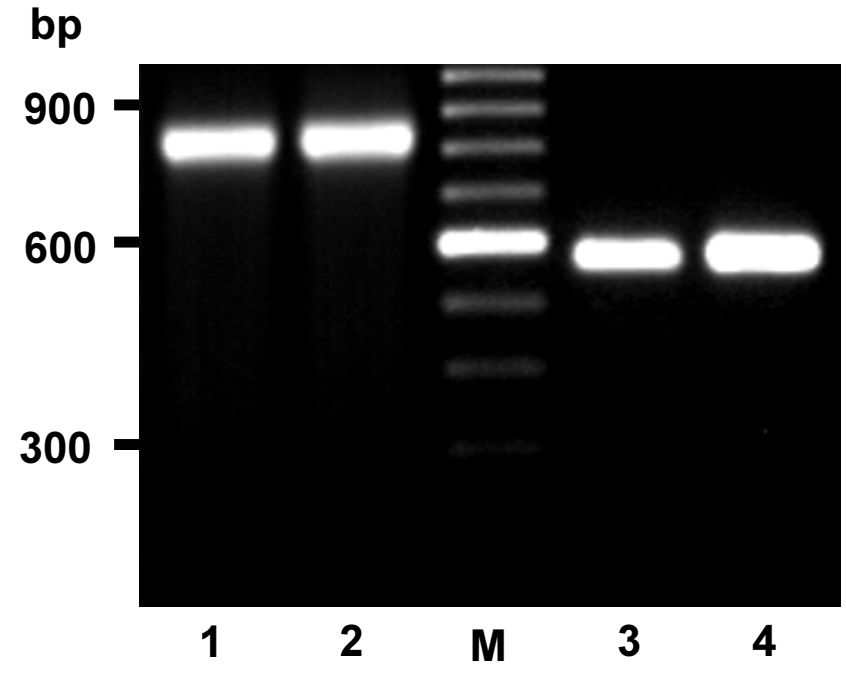

Figure I

Expression of IFN $\gamma$ receptors (IFN $\gamma \mathbf{R}$ ) in neuroendocrine gastrointestinal tumor cells. mRNA expression of IFN $\gamma R$ was evaluated in human pancreatic carcinoid BON tumor cells (lane 3). Neuroendocrine differentiated colorectal carcinoma cells (Colo320 DM) served as positive control for IFN $\gamma R$ (lane 4). $\beta$-actin was used as loading control (lane I: BON, lane 2: Colo320 DM). PCR products were visualized by gel electrophoresis on an ethidium bromide-stained agarose gel. M: 100 bp DNA ladder.

\section{Growth inhibition by IFN $\gamma$}

Changes in cell number induced by IFN $\gamma$ were studied by performing crystal violet assays. IFN $\gamma(0-500 \mathrm{U} / \mathrm{ml})$ timeand dose-dependently inhibited the growth of both BON and STC-1 cells. After 5 days of incubation a decrease in cell number of up to $90 \%$ was observed in BON cells (Fig. 2a). In slower growing STC-1 cells a decrease of up to $75 \%$ was observed after 5 days of incubation (Fig. 2b). The $\mathrm{IC}_{50}$ values of IFN $\gamma$, determined after $72 \mathrm{~h}$ of incubation, amounted to $135 \pm 10 \mathrm{U} / \mathrm{ml}$ in BON cells and $95 \pm 15 \mathrm{U} /$ $\mathrm{ml}$ in STC-1 cells.

\section{Additive antiproliferative effects of IFN $\gamma$ and MIBG}

Recently, we showed that non-radiolabeled MIBG specifically inhibited the growth of norepinephrine transporter (NET)-expressing STC-1 tumor cells $\left(\mathrm{IC}_{50} \sim 8 \mu \mathrm{M}\right)$ and that MIBG-treatment increased the expression of IFN $\gamma$ receptors. Vice versa, IFN $\gamma$ also enhanced MIBG-uptake [13]. Hence, we additionally evaluated antiproliferative effects of a combination treatment of NE gastrointestinal tumor cells with IFN $\gamma$ and MIBG.

In STC- 1 cells sub-IC ${ }_{50}$ concentrations of IFN $\gamma(10-100 \mathrm{U} /$ $\mathrm{ml})$ and MIBG (1-5 $\mu \mathrm{M})$ produced impressive additive growth inhibitory effects (Fig. 3a). The combination of
$100 \mathrm{U} / \mathrm{ml}$ IFN $\gamma$ with $5 \mu \mathrm{M}$ MIBG decreased the proliferation of STC-1 cells by 95\%. Such an antiproliferative effect was reached by MIBG alone only with concentrations of at least $25 \mu \mathrm{M}$.

Using RT-PCR we also demonstrated the expression of plasma membrane bound NET in BON cells which had not yet been investigated with regard to NET expression (Fig. 4a). Proliferation assays revealed that MIBG (1-100 $\mu \mathrm{M})$ dose- and time-dependently inhibited the growth of BON cells by up to $68 \pm 3.4 \%$. The $\mathrm{IC}_{50}$ value of MIBG, determined after $48 \mathrm{~h}$ of incubation, amounted to $47.4 \pm$ $2.1 \mu \mathrm{M}$ being distinctly higher than in STC-1 cells. Pretreating BON cells with IFN $\gamma(10-500 \mathrm{U} / \mathrm{ml})$ influenced the expression of MIBG-transporting NET. Semiquantitative RT-PCR revealed an IFN $\gamma$-induced increase of NET expression in BON cells by up to $200 \%$ after 48 h (Fig. $4 \mathrm{~b})$. However, upregulation of NET expression did not result in an overadditive antiproliferative effect of IFN $\gamma$ (10-100 U/ml) plus MIBG $(10-20 \mu \mathrm{M})$. Like in STC-1 cells, additive antiproliferative effects of IFN $\gamma$ and MIBG were observed in BON cells (Fig. 3b). The combination of $100 \mathrm{U} / \mathrm{ml}$ IFN $\gamma$ with $10 \mu \mathrm{M}$ MIBG produced antiproliferative effects that were comparable to those achieved by 50 $\mu \mathrm{M}$ MIBG on its own.

\section{IFN $\gamma$ and cell cycle regulation}

Flow cytometric analysis revealed that challenging $\mathrm{BON}$ cells for $48 \mathrm{~h}$ with rising concentrations of IFN $\gamma(0-500 \mathrm{U} /$ $\mathrm{ml}$ ) dose-dependently arrested the cells in the S-phase of the cell cycle, thereby decreasing the proportion of cells in the $\mathrm{G}_{2} / \mathrm{M}$-phase. S-phase arrest was significant for 250$500 \mathrm{U} / \mathrm{ml}$ IFN $\gamma$ (Fig. 5). The effect of MIBG treatment on the cell cycle of BON cells was also evaluated. In contrast to slow-growing STC-1 cells, not displaying cell cycle arresting effects in response to MIBG-treatment [13], BON cells showed a significant and dose-dependent arrest in the $G_{0} / G_{1}$-phase of the cell cycle after treatment with MIBG (10-50 $\mu \mathrm{M})$. Accordingly, the proportion of cells in the $\mathrm{G}_{2} / \mathrm{M}$-phase decreased.

Co-application of IFN $\gamma(10-100 \mathrm{U} / \mathrm{ml})$ and MIBG (50 $\mu \mathrm{M}$ ) resulted in an abrogation of the MIBG-induced $\mathrm{G}_{0} /$ $\mathrm{G}_{1}$-phase arrest, while the proportion of cells in the Sphase significantly increased as compared to MIBG-treatment alone. Interestingly, the S-phase arrest induced by combination treatment with $100 \mathrm{U} / \mathrm{ml}$ IFN $\gamma$ and $50 \mu \mathrm{M}$ MIBG was as strong as the one achieved by $500 \mathrm{U} / \mathrm{ml}$ IFN $\gamma$ alone (Fig. 5).

\section{Proapoptotic effects of IFN $\gamma$}

To check whether an induction of programmed cell death contributed to the antineoplastic effects of IFN $\gamma$, we investigated IFN $\gamma$-induced activation of caspase-3, a key enzyme in the apoptotic signaling pathway. Above $10 \mathrm{U} /$ 


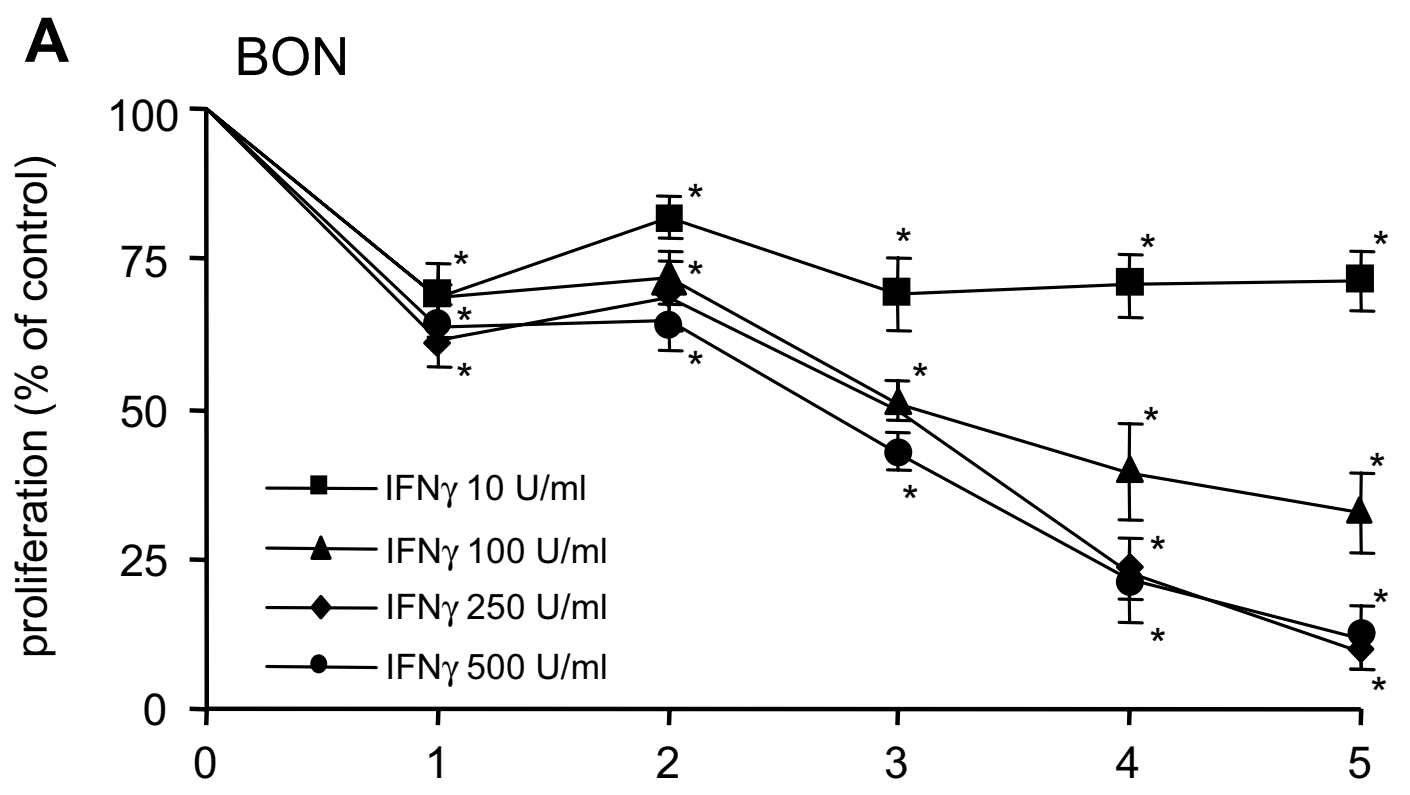

days of incubation

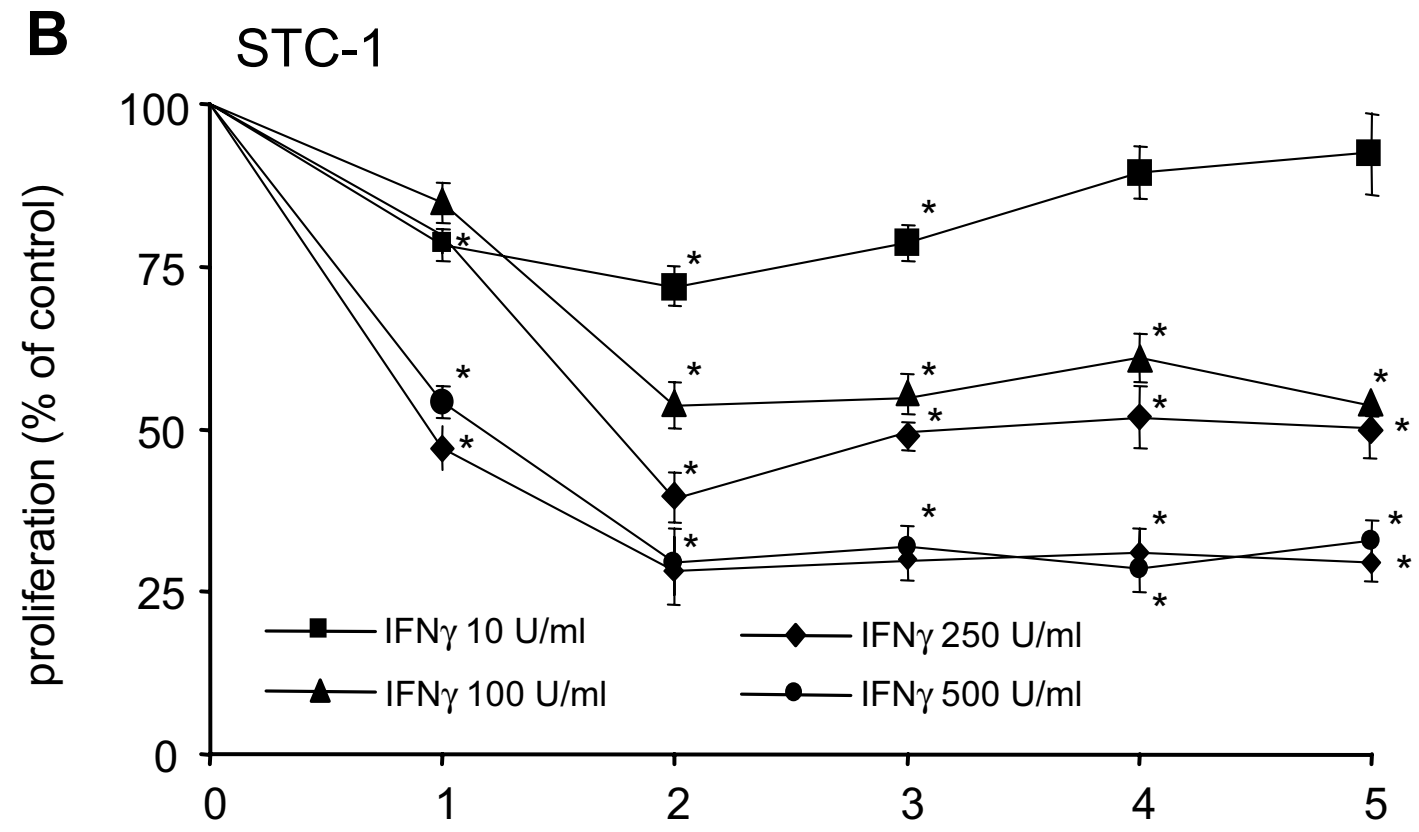

days of incubation

Figure 2

IFN $\gamma$-induced growth inhibition Rising concentrations of IFN $\gamma$ for 5 days led to a time- and dose-dependent growth inhibition of neuroendocrine gastrointestinal tumor cells, as measured by crystal violet staining. The growth of BON tumor cells was inhibited with an $I_{50}$ value of $135 \pm 10 \mathrm{U} / \mathrm{ml}(\mathbf{A})$. STC-I cells displayed an $I_{50}$ value of about $100 \mathrm{U} / \mathrm{ml}(95 \pm \mathrm{I} 5 \mathrm{U} / \mathrm{ml})(\mathbf{B})$. Data are given as percentage of untreated controls (means \pm SEM of 4 experiments). $*$, statistical significance $(p<0.05)$ compared to untreated controls. 

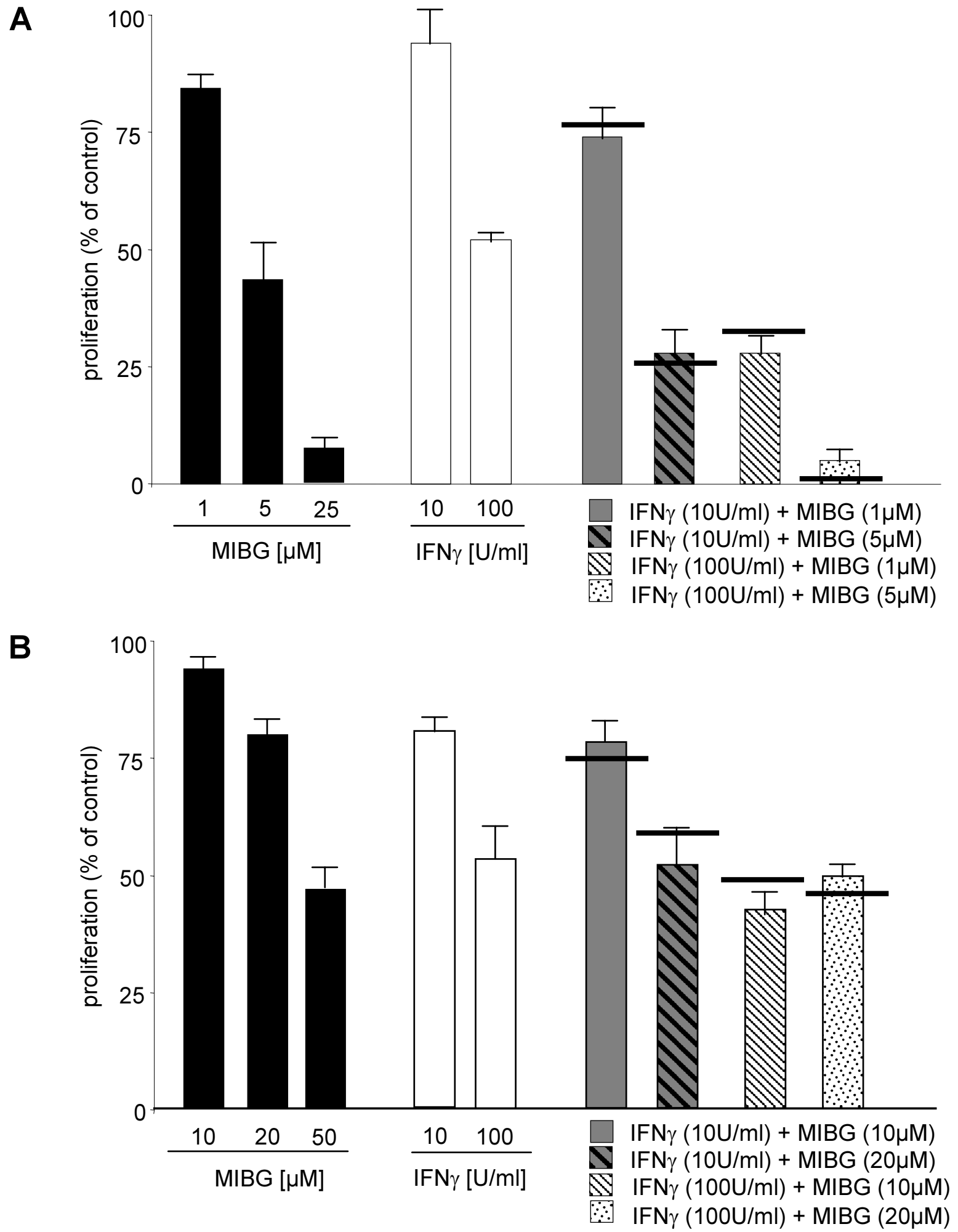

Figure 3

Antiproliferative effects of combination treatment with IFN $\gamma$ and MIBG A combination treatment with sub-IC ${ }_{50}$ concentrations of IFN $\gamma$ and MIBG for $72 \mathrm{~h}$ led to additive growth inhibitory effects in STC-I (A) and BON cells (B). Black bars indicate the values of a calculated additive growth inhibition. Data are given as percentage of untreated controls (means \pm SEM of 3 experiments). 


\section{A}
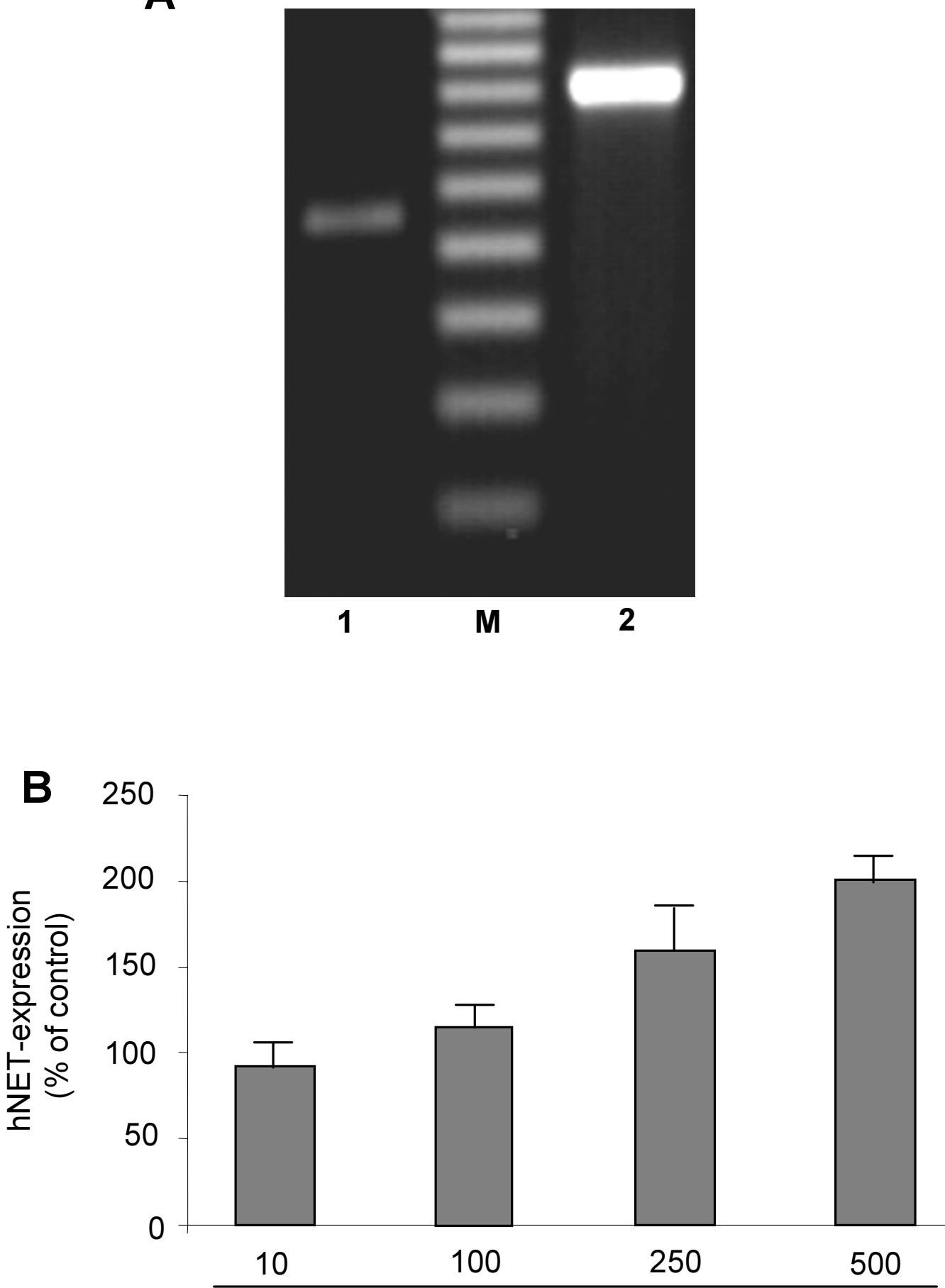

$\mathrm{IFN} \gamma[\mathrm{U} / \mathrm{ml}]$

\section{Figure 4}

mRNA expression of human norepinephrine transporters (hNET) mRNA expression of norepinephrine transporters was evaluated in BON cells. A: Transcripts specific for hNET were detected by RT-PCR (lane I). $\beta$-actin was used as loading control (lane 2). PCR products were visualized by gel electrophoresis on an ethidium bromide-stained agarose gel. M: 100 bP DNA ladder. B: Up-regulation of hNET expression by IFN $\gamma$. Semi-quantitative RT-PCR revealed a dose-dependent induction of hNET expression in BON cells by IFN $\gamma$ after $48 \mathrm{~h}$. Data are given as means \pm SEM of 2 experiments. 

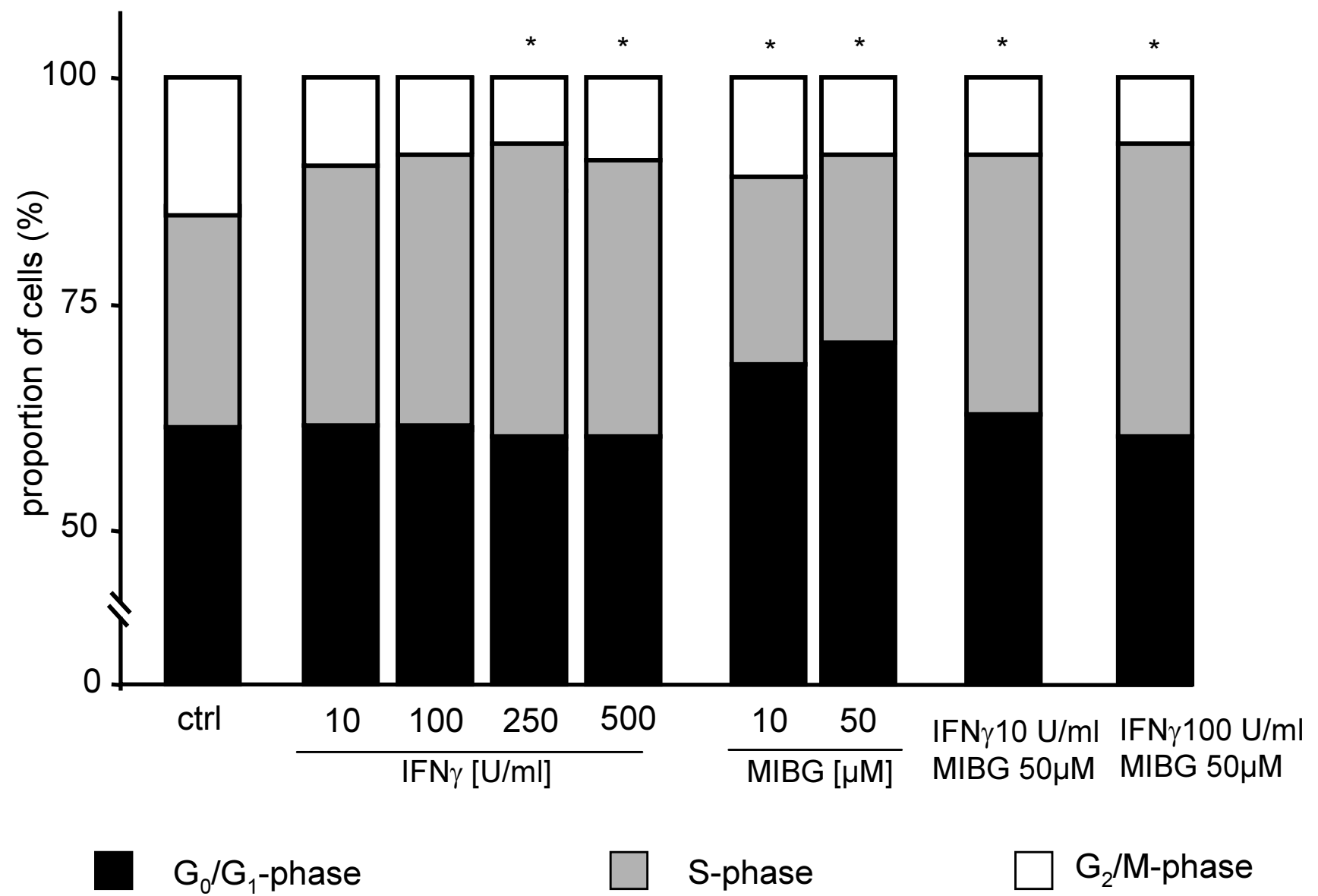

\section{S-phase}

$\mathrm{G}_{2} / \mathrm{M}$-phase

Figure 5

Induction of cell cycle arrest by IFN $\gamma$ and MIBG After $48 \mathrm{~h}$ of incubation IFN $\gamma$ dose-dependently induced an arrest in the $\mathrm{S}$-phase of the cell cycle of BON cells. Accordingly, the proportion of cells in the $\mathrm{G}_{2} / \mathrm{M}$-phase decreased. Differences in the proportion of cells in the respective phase of cell cycle versus control were significant from 250 to $500 \mathrm{U} / \mathrm{ml} \mathrm{IFN} \gamma$ (p $<0.05$ ). Incubation of BON cells with MIBG for $48 \mathrm{~h}$ induced a dose-dependent arrest in the $\mathrm{G}_{0} / \mathrm{G}_{1}$-phase, while the proportion of cells in the $\mathrm{G}_{2} / \mathrm{M}$-phase decreased. Differences in the proportion of cells in the respective phase of cell cycle versus control were significant at 10 and $50 \mu$ M MIBG $(p<0.05)$. Combination treatment of MIBG and IFN $\gamma$ abolished MIBG-induced $G_{0} / G_{1}-p h a s e$ arrest. Means of 4 independent experiments are shown.

ml IFN $\gamma$ induced caspase- 3 activation in both STC- 1 and BON cells after $48 \mathrm{~h}$ of incubation (Fig. 6a). No significant increase in IFN $\gamma$-induced caspase-3 activity was observed at concentrations higher than $100 \mathrm{U} / \mathrm{ml}$ or $250 \mathrm{U} / \mathrm{ml}$ IFN $\gamma$. Unexpectedly, co-treatment with IFN $\gamma$ (10-100 U/ $\mathrm{ml})$ plus MIBG (1-2 $\mu \mathrm{M}$ for STC-1 cells; $10-20 \mu \mathrm{M}$ for BON cells) led to subadditive caspase-3 activation in either BON or STC-1 cells (Fig 6b,6c).

\section{IFN $\gamma$-induced cytotoxicity}

Cytotoxic loss of cellular membrane integrity was measured by LDH release assay. Incubating BON cells with 10$500 \mathrm{U} / \mathrm{ml}$ IFN $\gamma$ for $48 \mathrm{~h}$ resulted in a pronounced and dose-dependent increase in LDH release (Fig. 7a). Additionally, we analyzed MIBG-induced cytotoxicity in BON cells. Treatment with MIBG for $48 \mathrm{~h}$ also dose-dependently increased the LDH-release of BON cells (Fig. 7b). The combination of IFN $\gamma(10-100 \mathrm{U} / \mathrm{ml})$ and MIBG (10$50 \mu \mathrm{M}$ ) resulted in a marked overadditive $\mathrm{LDH}$ release from BON cells (Fig. 7c). Compared to the calculated values of an assumed additive cytotoxicity (indicated as black bars in the columns of Fig. 7c), the actual LDH-release induced by $100 \mathrm{U} / \mathrm{ml}$ IFN $\gamma$ plus $50 \mu \mathrm{M}$ MIBG was about $32 \pm 4 \%$ higher than the calculated sum. The combination of the lowest doses of IFN $\gamma(10 \mathrm{U} / \mathrm{ml})$ and MIBG $(10 \mu \mathrm{M})$ surmounted the calculated sum of each effect by $188 \pm$ 
A
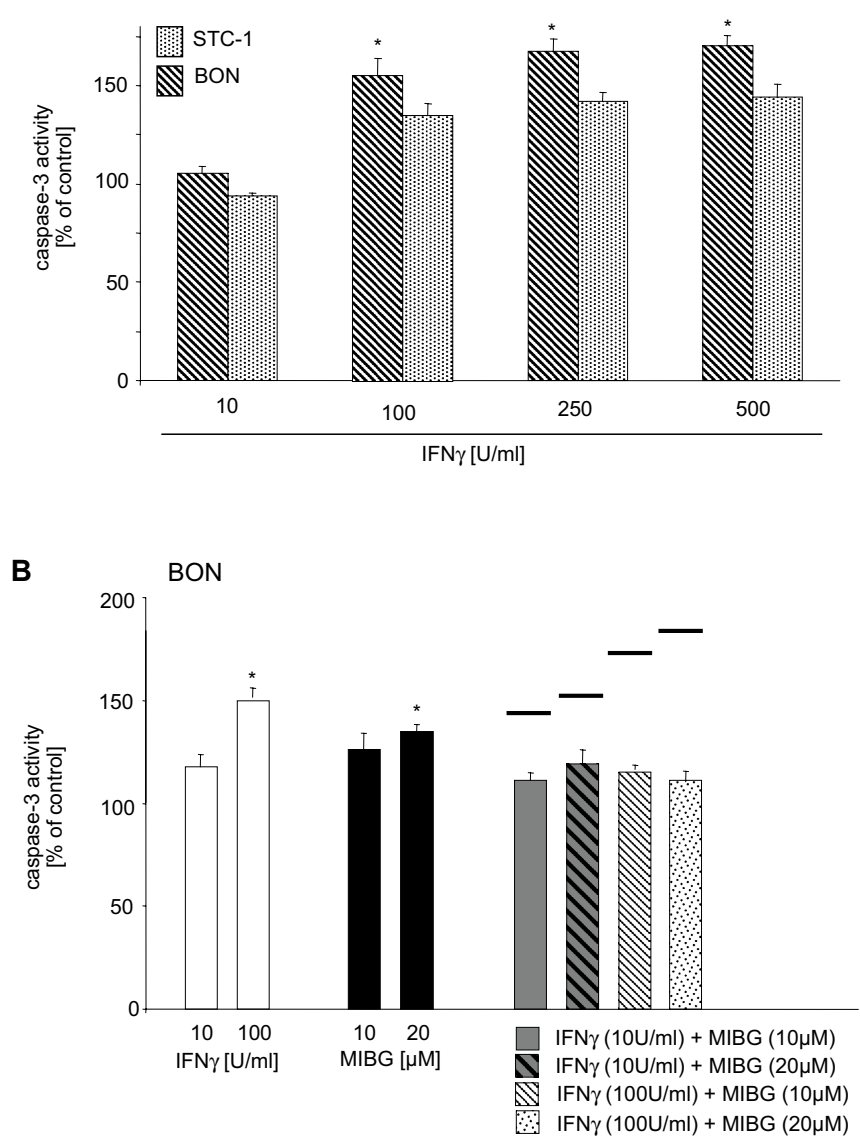

C

STC-1

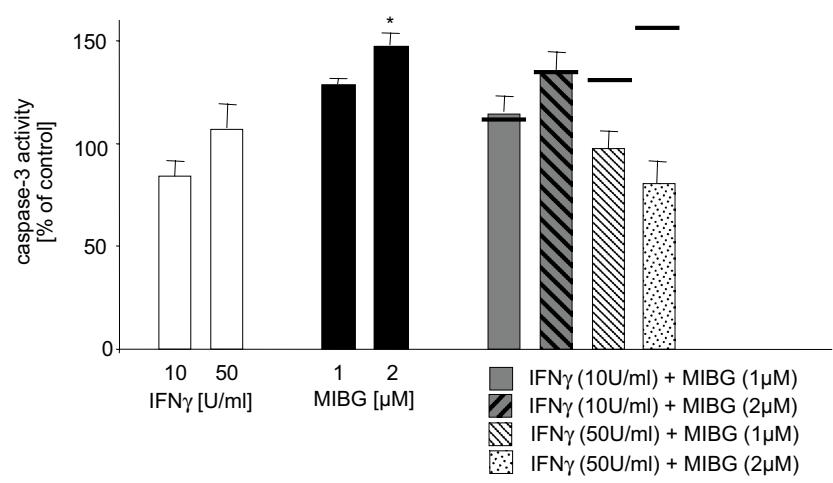

Figure 6

Induction of apoptosis by IFN $\gamma$ and MIBG A: IFN $\gamma$ induced apoptosis specific caspase-3 activity in BON and STC-I cells after $48 \mathrm{~h}$ of incubation. B: MIBG-treatment (48 h) dose-dependently increased caspase-3 activity of BON cells. Interestingly, combination treatment with IFN $\gamma$ and MIBG resulted in sub-additive caspase- 3 activation. Black bars indicate the calculated additive values of caspase-3 activation of either combination. C: MIBG-treatment (48 h) dose-dependently increased caspase-3 activity of STC-I cells. Co-incubation with IFN $\gamma$ and MIBG led to sub-additive caspase-3 activation. Black bars indicate the calculated additive values of caspase-3. Data are given as means \pm SEM of 3 (STC-I) or 4 (BON) independent experiments. *, statistical significance $(p<0.05)$ compared with untreated controls. 
A B

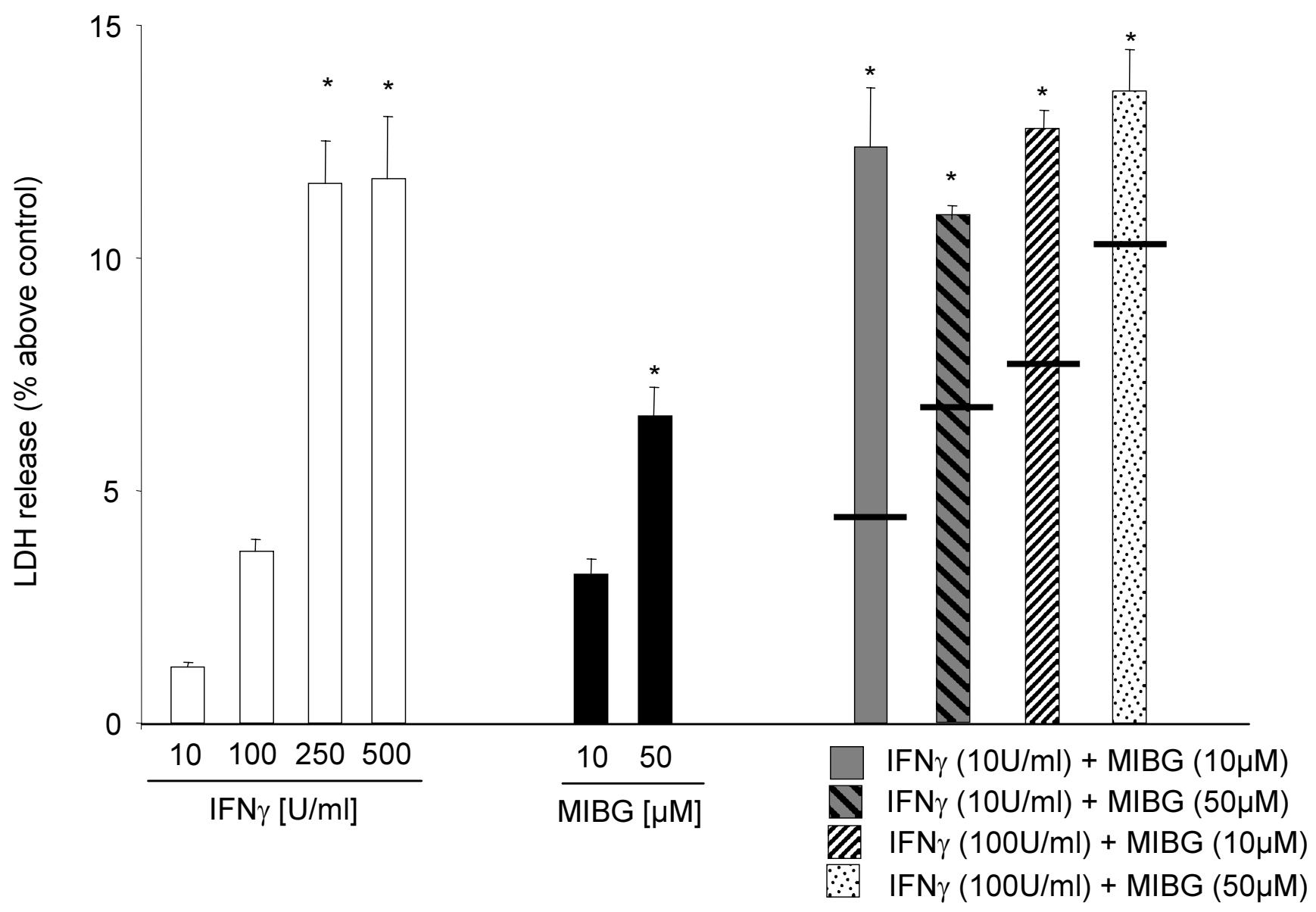

Figure 7

IFN $\gamma$ induced cytotoxicity. Cytotoxicity of IFN $\gamma$ was evaluated by lactate dehydrogenase (LDH) release from IFN $\gamma$-treated BON cells. A: After $48 \mathrm{~h}$ of incubation, IFN $\gamma$ induced a dose-dependent increase in LDH release. B: MIBG-treatment (48 h) also induced cytotoxicity in BON cells in a dose-dependent manner. $\mathbf{C}$ : Interestingly, co-treatment of BON cells with IFN $\gamma$ and MIBG resulted in an over-additive LDH release. Black bars indicate the calculated additive values of LDH release of either combination. Data are given as the relative increase in LDH release compared to untreated controls (means \pm SEM of 4 independent experiments). ${ }^{*}$, statistical significance $(p<0.05)$ compared with untreated controls.

$12 \%$. Thus, the cytotoxic effect of a "low-dose combination" of IFN $\gamma$ and MIBG was as pronounced as the one obtained by $500 \mathrm{U} / \mathrm{ml}$ IFN $\gamma$ alone.

\section{Discussion}

Although excellent control of tumor-associated hypersecretion syndromes of neuroendocrine gastrointestinal tumors can be achieved by biotherapy with somatostatin analogs or IFN $\alpha$, systemic treatment options to inhibit the growth and further spread of metastatic neuroendocrine tumors are still unsatisfactory. For instance, IFN $\alpha$ although excellently controling hypersecretion in most cases [2], has been shown to cause only a partial tumor remission in less than $20 \%$ of treated patients $[1,7,26]$. Novel treatment modalities are therefore needed.

Here, we report on the antineoplastic effects of IFN $\gamma$, a cytokine which has already been shown to exert growth inhibitory effects in vitro in several non-neuroendocrine cancer models, including breast [27], hepatocellular [28], ovarian [29] and colorectal carcinoma [30,31] or glioblastoma [32]. Also in vivo, IFN $\gamma$ has been demonstrated to be beneficial as a first line therapeutic agent for ovarian cancer [33] or as a supportive drug for enhanced 
chemoimmunotherapeutic regimes of metastatic melanoma [34]. Nevertheless, in other cancers (i.e., renal cell carcinoma or SCLC) IFN $\gamma$ did not show any appreciable beneficial antineoplastic action in man $[35,36]$, arguing for a distinctive tumor species-dependent effect of the cytokine. As IFN $\gamma$-mediated growth control of a particular tumor type does apparently not allow to predict similar effects in other tumor species, it was all the more important to investigate IFN $\gamma$ 's antineoplastic action in neuroendocrine gastrointestinal tumor cells. Here we provide evidence that IFN $\gamma$ potently inhibits growth of neuroendocrine gastrointestinal tumor cells. When IFN $\gamma$ was combined with MIBG, an even more pronounced antiproliferative effect was obtained.

As the growth pattern of NE gastrointestinal tumors exhibits a wide spectrum ranging from very slow to fast growing types [37], it was important to study IFN $\gamma$-induced growth inhibition in NE tumor cell lines with different growth characteristics and of different origin. We chose two models of NE gastrointestinal tumor disease: First, human pancreatic carcinoid BON cells with a doubling time of 34 $h$, and second, NE tumor cells of the gut (STC-1 cells) with a doubling time of $54 \mathrm{~h} \mathrm{[38].} \mathrm{In} \mathrm{either} \mathrm{NE} \mathrm{tumor} \mathrm{model}$ we observed growth inhibitory effects of IFN $\gamma$ with IC $_{50}$ values of about $100 \mathrm{U} / \mathrm{ml}$ and maximal growth inhibition by $75-90 \%$ at $\geq 250 \mathrm{U} / \mathrm{ml}$ IFN $\gamma$. As these concentrations are within the therapeutically achievable range of IFNplasma levels in humans [25], IFN $\gamma$ appears to be a promising agent for innovative growth inhibition of NE gastrointestinal tumor cells.

The signaling pathways mediating IFN $\gamma$ 's antineoplastic action differ between various tumor types and lead to distinct biological responses, such as $\mathrm{G}_{1}$-arrest [39], S-phase arrest $[40,41]$, induction of apoptosis $[24,28]$ and cytotoxicity [42].

To further characterize the antiproliferative action of IFN $\gamma$ in NE gastrointestinal tumor cells, we performed cell cycle analyses. Flow cytometry with isolated nuclei of IFN $\gamma$ treated BON tumor cells, revealed a significant increase in the proportion of cells in the S-phase. Cell cycle arrest by IFN $\gamma$ in the S-phase had previously been described for other tumors such as glioblastomas [32], but other reports described a $G_{0} / G_{1}$-arrest in response to IFN $\gamma$ treatment $[6,7,43]$. The accumulation of NE gastrointestinal tumor cells in the S-phase of the cell cycle may be of great value for novel combination treatments with established antimetabolic chemotherapeutics such as 5-fluorouracil, which interfere with DNA-synthesis [44]. Thus, the Sphase arresting cytostatic drug irinotecan enhances the antiproliferative efficacy of 5-fluorouracil in colon cancer [45].
Moreover, we observed an induction of apoptosis in neuroendocrine gastrointestinal tumor cells by IFN $\gamma$. Concerning the underlying mechanisms of IFN $\gamma$-induced apoptosis both indirect mechanisms like an increase in TNF- $\alpha$ sensitivity [46], an upregulation of CD95 receptor expression [47] or a modulation of human leukocyte antigen molecules (HLA) [48], and direct mechanisms like the upregulation and activation of caspases have been shown $[24,49]$. In BON and STC-1 cells we found a dose-dependent induction of apoptosis via proapoptotic caspase-3 activation. This direct mechanism has been previously described by Detjen et al. [50] in neuroendocrine QGP-1 tumor cells. In OGP- 1 cells IFN $\gamma$-mediated apoptosis was found to require intermediate signaling steps such as induction of the interferon regulatory factor IRF-1 and subsequent activation of the initiator caspase-1, which accounted for the relatively long time to response of IFN $\gamma$ induced apoptosis. Caspase-1-mediated activation of downstream caspases in response to IFN $\gamma$ has been reported for other cell models, like leukemia cells [51], vascular smooth muscle cells [52] and HeLa cells [53]. It is intriguing to speculate, that also in the BON and STC-1 tumor models IFN $\gamma$-mediated apoptosis involved such intermediary signaling steps, since caspase- 3 activation in BON and STC-1 cells was not detectable earlier than after $48 \mathrm{~h}$ of incubation with IFN $\gamma$. In order to fully understand the signaling events of IFN $\gamma$-induced apoptosis in neuroendocrine tumor cells further investigations are required.

Growth inhibition of NE tumor cells by IFN $\gamma$ also involves cytotoxcicity. At least at high concentrations of IFN $\gamma$, BON cells displayed a significant increase in LDH release. Interestingly, at the half-maximal growth inhibitory IFN $\gamma$ concentration of $100 \mathrm{U} / \mathrm{ml}$ neither a significant increase in cytotoxicity nor a significant S-phase arrest could be observed, and only caspase-3 activity was significantly increased. Thus, at lower concentrations IFN $\gamma$ appears to control growth of NE tumor cells mainly by apoptosis, whereas at higher concentrations other mechanisms are involved.

The second goal of our study was to explore the growth inhibitory effects of a combination treatment of IFN $\gamma$ and non-radiolabeled meta-iodobenzylguanidine (MIBG). The rationale for investigating this particular combinbation was first, that non-radiolabeled MIBG was a potent NE tumor-specific antineoplastic drug $[11,38]$, and second, that IFN $\gamma$ enhanced the uptake of MIBG by increasing the expression of norepinephrine transporters in neuroblastoma cells [13]. Moreover, we recently showed that MIBG induced an overexpression of IFN $\gamma$-receptors in NE gastrointestinal tumor cells [11]. These results suggested possible synergistic action of a combination treatment of IFN $\gamma$ and MIBG. Intriguingly, combining sub-IC ${ }_{50}$ 
concentrations of IFN $\gamma$ and MIBG led to growth inhibition of up to $95 \%$. In STC-1 cells, the combination of IFN $\gamma$ and MIBG exeeded the maximal antiproliferative effect of IFN $\gamma$ alone by more than $20 \%$. To achieve $90 \%$ growth inhibition of STC-1 cells by MIBG alone, concentrations beyond $25 \mu \mathrm{M}$ were needed. Thus, combining IFN $\gamma$ and MIBG allows to reduce the concentration of either agent to one fifth without losing excellent growth control. The same holds true for BON cells, which also displayed enhanced growth inhibition in response to sub$\mathrm{IC}_{50}$ concentrations of IFN $\gamma$ and MIBG. The potential of this novel combination treatment strategy will have to be evaluated in future clinical studies.

To further investigate underlying mechanisms of the proposed combination therapy, we evaluated IFN $\gamma$-induced norepinephrine transporter expression, apoptosis, cell cycle regulation and cytotoxicity in BON cells. Our results indicate that an overexpression of norepinephrine transporters does not account for enhanced growth inhibition by IFN $\gamma$ plus MIBG. Although IFN $\gamma$ induced the expression of norepinephrine transporters (NET) in neuroendocrine gastrointestinal tumor cells, the IFN $\gamma$ concentrations required to achieve a marked increase in NET expression were far above the antiproliferative $\mathrm{IC}_{50}{ }^{-}$ value of about $100 \mathrm{U} / \mathrm{ml}$. Hence, our data indicate that an enhanced MIBG-uptake due to an IFN $\gamma$-induced overexpression of NET cannot be achieved with IFN $\gamma$ concentrations, suitable for combination treatment.

Unexpectedly, the combination of MIBG and IFN $\gamma$ resulted in a sub-additive caspase- 3 activation as compared to treatment with either drug alone. Furthermore, we found an abrogation of MIBG-induced $G_{0} / G_{1}$-phase arrest in BON cells that had been co-treated with S-phase arresting IFN $\gamma$. Thus, MIBG and IFN $\gamma$ appear to modulate distinct signaling pathways to induce apoptosis and cell cycle arrest in NE tumor cells. Due to yet unknown interferences in the signaling events, the effects on apoptosis and cell cycle were less pronounced and even sub-additive. Thus, it will be of future interest to identify the signaling molecules involved in this interference to gain insight into the underlying regulatory processes at the molecular level. However, sub-additive cell cycle arrest has already been found for other drug combinations, like the combination of 5-fluorouracil and cisplatin in colon cancer. In contrast to our findings the sub-additive cell cycle arrest of 5-fluorouracil and cisplatin led to a reduced growth inhibition than with 5-fluorouracil alone [54].

Despite of the reduced apoptosis and cell cycle arrest the growth inhibition obtained by IFN $\gamma$ plus MIBG was additive in NE tumor cells. The most likely explanation of these conflicting results is a synergistic increase in cytotoxicity in resopnse to IFN $\gamma$ plus MIBG. While almost no cytotoxicity was seen for either drug alone, the combination of low doses of MIBG and IFN $\gamma$ led to a pronounced and significant synergistic increase in cytotoxicity. Concentrations as high as $500 \mathrm{U} / \mathrm{ml}$ were needed to achieve comparable cytotoxic effects by IFN $\gamma$ alone. The underlying mechanisms are yet unknown, but have to be studied in the future. Anyway, the very fact, that co-treatment of NE tumor cells with IFN $\gamma$ and MIBG exerts such a pronounced cytotoxic effect may be of potential clinical value: As the expression of MIBG-transporting norepinephrine transporters in extraneuronal locations is limited or low (e.g., heart, renal medulla, lung endothelial cells), the relative specific and exclusive NET (over) expression in neuroendocrine gastrointestinal tumor cells forms a basis for NE tumor-targeted treatment [55]. Thus, a low concentration of MIBG renders an ineffective concentration of IFN $\gamma$ cytotoxic in NE tumor cells. It can therefore be speculated that the combination of IFN $\gamma$ with MIBG may induce a NE tumor cell-specific killing with reduced sideeffects in normal cells. Future clinical studies will have to clarify the actual effects in vivo.

\section{Conclusions}

Our study provides evidence that IFN $\gamma$ induces both cell cycle arrest and apoptosis in NE gastrointestinal tumor cells. Moreover, IFN $\gamma$ can be effectively combined with non-radiolabeled MIBG in order to achieve excellent growth control at low concentrations of either drug. Thus, IFN $\gamma$ represents a promising novel drug to be tested in patients with metastatic NE gastrointestinal tumor disease.

\section{List of abbreviations}

IFN $\gamma$, interferon gamma

IRF, interferon regulatory factor

MW, molecular weight

MIBG, meta-iodobenzylguanidine

PBS, phosphate-buffered $\mathrm{NaCl}$ solution

RT-PCR, reverse transcriptase-polymerase chain reaction

STAT, signal transducers and activators of transcription

\section{Competing interest}

None declared.

\section{Authors' contributions}

$\mathrm{MH}$ : writing, study design, experimental design, investigation of growth inhibition and apoptosis; APS: cell cycle analysis by flow cytometry; AH: cytotoxicity studies; G AH: RT-PCR, interpretation of the data; HS: study design, 
writing. All authors read and approved the final manuscript.

\section{Acknowledgements}

We thank Antje Krahn and B. Ergün for excellent technical assistance. We are indebted to the Institute of Physiology, Charité University Medicine Berlin, Germany, for laboratory facilities. This study was supported by grants of the Deutsche Forschungsgemeinschaft and the Sonnenfeld-Stiftung.

\section{References}

I. Faiss S, Scherübl H, Riecken EO, Wiedenmann B: Drug therapy in metastatic neuroendocrine tumors of the gastroenteropancreatic system. Recent Results Cancer Res 1996, 142:193-207.

2. Öberg K: Chemotherapy and biotherapy in the treatment of neuroendocrine tumors. Ann Oncol 200 I, I 2:SI II-SI I4.

3. Bromberg J, Darnell JE jr: The role of STATs in transcriptional control and their impact on cellular function. Oncogene 2000, 1 9:2468-2473.

4. Meraz MA, White JM, Sheehan, Bach EA, Rodig SJ, Dighe AS, Kaplan DH, Riley JK, Greenlund AC, Campbell D, Carver-Moore K, DuBois RN, Clark R, Aguet M, Schreiber RD: Targeted disruption of the STAT-I gene in mice rerveals unexpeted physiologic specificity in the JAK-STAT signaling pathway. Cell 1996, 84:43 I-442.

5. Burke F, Smith PD, Crompton MR, Upton C, Balkwill FR: Cytotoxic response of ovarian cancer cell lines to IFN $\gamma$ is associated with sustained induction of IRF-I and P2I mRNA. Br J Cancer 1999, 80: 1236-1244.

6. Hoshiya Y, Gupta V, Kawakubo H, Brachtel E, Carey JL, Sasur L, Scott A, Donahoe PK, Maheswaran S: Mullerian inhibiting substance promotes IFN gamma-induced gene expression and apoptosis in breast cancer cells. J Biol Chem 2003, 278:51503-51712.

7. Läuffer JM, Zhang T, Modlin IM: Review article: current status of gastrointestinal carcinoids. Aliment Pharamcol Ther 1999, 13:27I-287.

8. Hoefnagel CA, Voute PA, de Kraker J, Marcuse HR: Radionuclide diagnosis and therapy of neural-crest tumors using $131 \mathrm{I}$ meta-iodobenzylguanidine. J Nucl Med I987, 28:308-3I4.

9. Taal BG, Hoefnagel CA, Boot $\mathrm{H}$, Olmos Valdes RAV, Rutgers $M$ : Improved effect of [I3II]-MIBG treatment by predosing with nonradiolabeled MIBG in carcinoid patients, and studies in xenografted mice. Ann Oncol 2000, I I: I 437-I 443.

10. Taal BG, Hoefnagel CA, Olmos Valdes RAV, Boot H, Beijnen JH: Palliative effect of meta-iodobenzylguanidine in metastatic carcinoid tumors. J Clin Oncol 1996, I 4:1829-1238.

II. Höpfner M, Sutter AP, Beck N, Barthel B, Maaser K, Zeitz M, Scherübl $\mathrm{H}$ : Meta-iodobenzylguanidine induced growth inhibition and apoptosis of neuroendocrine gastrointestinal tumor cells. Int J Cancer 2002, 101:210-216.

12. Zuetenhorst H, Taal B, Bootm H, Valdes Olmos R, Hoefnagel C: Long-term palliation in metastatic carcinoid tumors with varoius applications of meta-iodobenzylguanidin (MIBG): pharmacological MIBG, I3II-labelled MIBG and the combination. Eur J Gastroenterol Hepatol 1999, I I: | | 57- I | 64.

13. Montaldo PG, Raffaghello L, Guarnaccia F, Pistoia V, Garaventa A, Ponzoni M: Increase of metaiodobenzylguanidine uptake and intracellular half-life during differentiation of human neuroblastoma cells. Int J Cancer 1996, 67:95-100.

14. Lemmer K, Ahnert-Hilger G, Höpfner M, Hoegerle S, Faiss S, Grabowski P, Jockers-Scherübl M, Riecken EO, Zeitz M, Scherübl H: Expression of dopamine receptors and transporter in neuroendocrine gastrointestinal tumor cells. Life Sci 2002, $71: 667-678$

15. Ahnert-Hilger G, Stadtbäumer A, Strübing C, Scherübl H, Schultz G, Riecken EO, Wiedenmann B: gamma-Aminobutyric acid secretion from pancreatic neuroendocrine cells. Gastroenterology 1996, I 1 0:1595-1604.

16. Jansen A, Höpfner M, Herzig KH, Riecken EO, Scherübl H: $\mathbf{G a b a}_{\mathrm{c}}$ receptors in neuroendocrine gut cells: a new GABA bindingsite in the gut. Eur J Physiol 2000, 44 I:294-300.

17. Park JG, Herbert KO, Sugarbaker PH, Henslee JG, Chen TR, Johnson BE, Gadzar A: Characteristics of cell lines established from human colorectal carcinoma. Cancer Res 1987, 47:6710-67।8.
18. Sutter AP, Maaser K, Barthel B, Scherubl H: Ligands of the peripheral benzodiazepine receptor induce apoptosis and cell cycle arrest in oesophageal cancer cells: involvement of the p38MAPK signalling pathway. Br J Cancer 2003, 89:564-572.

19. Glassmeier G, Herzig KH, Höpfner M, Lemmer K, Jansen A, Scherübl $\mathrm{H}$ : Expression of functional GABA $\mathrm{A}_{\mathrm{A}}$ receptors in cholecystokinin-secreting gut neuroendocrine murine STC-I cells. J Physiol (Lond) 1998, 5 10:805-8I4.

20. Höpfner M, Maaser K, von Lampe B, Hanski C, Riecken EO, Zeitz M, Scherübl H: Growth inhibition and apoptosis induced by $\mathbf{P}_{2} \mathbf{Y}_{2-}$ receptors in human colorectal carcinoma cells: Involvement of intracellular calcium and cyclic AMP. Int J Colorectal Dis 200I, 16:154-166.

21. Maaser K, Höpfner M, Jansen A, Weisinger G, Gavish M, Kozikowski AP, Weizman A, Carayon P, Riecken EO, Zeitz M, Scherübl H: Specific ligands of the peripheral benzodiazepine receptor induce apoptosis and cell cycle arrest in human colorectal cancer cells. Br J Cancer 200I, 85: I77I-I780.

22. Maaser K, Höpfner M, Kap H, Sutter AP, Barthel B, von Lampe B, Zeitz M, Scherübl H: Extracellular nucleotides inhibit growth of human oesophageal cancer cells via P2Y(2)-receptors. $\mathrm{Br} J$ Cancer 2002, 86:636-644.

23. Decker T, Lohmann-Matthes ML: A quick and simple method for the quantitation of lactate dehydrogenase release in measurements of cellular cytotoxicity and tumor necrosis factor (TNF) activity. J Immunol Methods 1988, I I 5:6 I-69.

24. Detjen KM, Farwig K, Welzel M, Wiedenmann B, Rosewicz S: Interferon gamma inhibits growth of human pancreatic carcinoma cells via caspase- $I$ dependent induction of apoptosis. Gut 200I, 49:25I-26I.

25. Detjen KM, Welzel M, Farwig K, Brembeck FH, Kaiser A, Riecken EO, Wiedenmann B, Rosewicz S: Molecular mechanism of interferon alfa-mediated growth inhibition in human neuroendocrine tumor cells. Gastroenterology 2000, I | 8:735-748.

26. Öberg $\mathrm{K}$ : Interferons in the management of neuroendocrine GEP-tumors: a review. Digestion 2000, 62:92-97.

27. Yim JH, Ro SH, Lowney JK, Wu SJ, Connett J, Doherty GM: The role of interferon regulatory factor-I and interferon regulatory factor-2 in IFN-gamma growth inhibition of human breast carcinoma cell lines. I Interferon Cytokine Res 2003, 23:50 I-5 I I.

28. Detjen KM, Murphy M, Welzel M, Farwig K, Wiedenmann B, Rosewicz S: Downregulation of $\mathrm{p} 2 \mathrm{I}$ waflcip-I mediates apoptosis of human hepatocellular carcinoma cells in response to interferon- $\gamma$. Exp Cell Res 2003, 282:78-89.

29. Seppanen M, Lin L, Punnonen J, Grenman S, Punnonen R, Vihko KK: Regulation of UT-OC-3 ovarian carcinoma cells by cytokines: inhibitory effects on cell proliferation and activation of transcription factors AP-I and NF-kappaB. Eur J Endocrinol 2000, I 42:393-40I.

30. Toth CA, Thomas P: The effect of interferon treatment on 14 human colorectal cancer cell lines: growth and carcinoembryonic antigen secretion in vitro. J Interferon Res 1990, 10:579-588

3I. Schiller JH, Bittner G, Storer B, Willson JK: Synergistic antitumor effects of tumor necrosis factor and gamma-interferon on human colon carcinoma cell lines. Cancer Res 1987, 47:2809-28I3.

32. Kominsky S, Johnson HM, Bryan G, Tanabe T, Hobeika AC, Subramaniam PS, Torres B: IFN-gamma inhibition of cell growth in glioblastomas correlates with increased levels of cyclin dependent knase inhibitor p2Iwaf/cip-I. Oncogene 1998, I 7:2973-2979.

33. Windbichler $\mathrm{GH}$, Hausmaninger $\mathrm{H}$, Stummvoll $W$, Graf $\mathrm{AH}$, Kainz $\mathrm{C}$, Lahodny J, Denison U, Müller-Holzner E, Marth C: Interferongamma in the first-line therapy of ovarian cancer: a randomized phase III trial. Br J Cancer 2000, 82: I | 38- | I 44.

34. Propper DJ, Chao D, Braybrooke JP, Bahl P, Thavasu P, Balkwill F, Turley H, Dobbs N, Gatter K, Talbot DC, Harris AL, Ganesan TS: Low-dose IFN-gamma induces tumor MHC expression in metastatic malignant melanoma. Clin Cancer Res 2003, 9:84-92.

35. Dutcher JP, Fine JP, Krigel RL, Murphy BA, Schaefer PL, Ernstoff MS, Loehrer PJ: Stratification by risk factors predicts survival on the active treatment arm in a randomized phase II study of interferon-gamma plus/minus interferon-alpha in advanced renal cell carcinoma (E6890). Med Oncol 2003, 20:27I-28I. 
36. van Zandwijk N, Groen HJ, Postmus PE, Burghouts JT, ten Velde GP, Ardizzoni A, Smith IE, Baas P, Sahmoud T, Kirkpatrick A, Dalesio O, Giaccone G: Role of recombinant interferon-gamma maintenance in responding patients with small cell lung cancer. $A$ randomised phase III study of the EORTC Lung Cancer Cooperative Group. Eur J Cancer 1997, 33: 1759- 1766.

37. Öberg K: Expression of growth factors and their receptors in neuroendocrine gut and pancreatic tumors, and prognostic factors for survival. Ann NY Acad Sci 1994, 733:46-55.

38. Höpfner M, Sutter AP, Gerst B, Zeitz M, Scherübl H: A novel approach in the treatment of neuroendocrine gastrointestinal tumours. Targeting the epidermal growth factor receptor by gefitinib (ZD I 839). Br J Cancer 2003, 89: I766- I775.

39. Amrani $Y$, Tliba O, Choubey D, Huang CD, Krymskaya VP, Eszterhas A, Lazaar AL, Panettieri RA Jr: IFN-gamma inhibits human airway smooth muscle cell proliferation by modulating the E2FI/Rb pathway. Am J Physiol Lung Cell Mol Physiol 2003, 284:LI 063-7I.

40. Sangfelt $O$, Erikson S, Grander D: Mechanisms of interferoninduced cell cycle arrest. Front Biosci 2000, 5:D479-D487.

4I. Vadiveloo PK, Vairo G, Novak U, Royston AK, Whitty G, Filonzi EL, Cragoe EJ jr, Hamilton JA: Differential regulation of cell cycle machinery by various antiproliferative agents linked to macrophage arrest at distinct GI checkpoints. Oncogene 1996, 1 3:599-608.

42. Rodrigues EG, Travassos LR: Endogenous accumulation of IFNgamma in IFN-gamma-R(-/-) mice increases resistance to B I6FI0-Nex2 murine melanoma: a model for direct IFNgamma anti-tumor cytotoxicity in vitro and in vivo. Cytokines Cell Mol Ther 2002, 7:107-1 I6.

43. Harvat BL, Jetten AM: Gamma-interferon induces an irreversible growth arrest in mid-GI in mammary epithelial cells which correlates with a block in hyperphosphorylation of retinoblastoma. Cell Growth Differ 1996, 7:289-300.

44. Mirjolet JF, Didelot C, Barberi-Heyob M, Merlin JL: G(I)/S but not $\mathbf{G}(0) / \mathbf{G}(\mathrm{I})$ cell fraction is related to 5 -fluorouracil cytotoxicity. Cytometry 2002, 48:6-13

45. Xu JM, Azzariti A, Tommasi S, Lacalamita R, Colucci G, Johnston PG Church SW, Paradiso A: Combination of 5-fluorouracil and irinotecan on modulation of thymidylate synthase and topoisomerase I expression and cell cycle regulation in human colon cancer LoVo cells: clinical relevance. Clin Colorectal Cancer 2002, 2:182-188.

46. Kim EJ, Lee JM, Namkoong SE, Um SJ, Park JS: Interferon regulatory factor- $I$ mediates interferon- $\gamma$-induced apoptosis in ovarian carcinoma cells. J Cellular Biochem 2002, 85:369-380

47. Nagata S: FAS-induced apoptosis. Intern Med 1998, 37:I79-18I.

48. Read SB, Kulprathipanja NV, Gomez GG, Paul DB, Winston KR, Robbins JM, Kruse CA: Human alloreactive CTL interactions with gliomas and with those having upregulated HLA expression from exogenous IFN-gamma or IFN-gamma gene modification. J Interferon Cytokine Res 2003, 23:379-393.

49. Tamura T, Ueda S, Yoshia M, Matsuzaki M, Mohri H, Okubo T: Interferon-gamma induces Ice gene expression and enhances cellular susceptibility to apoptosis in the U937 leukemia cell line. Biochem Biophys Res Commun 1996, 229:2I-26.

50. Detjen KM, Kehrberger JP, Drost A, Rabien A, Welzel M, Wiedenmann B, Rosewicz S: Interferon-gamma inhibits growth of human neuroendocrine carcinoma cells via induction of apoptosis. Int | Oncol 2002, 2 I : | | 33- | | 40.

5I. Tamura T, Ishihara M, Lamphier MS, Tanaka N, Oishi I, Aizawa S, Matsuyama T, Mak TW, Taki S, Taniguchi T: DNA damage-induced apoptosis and Ice gene induction in mitogenically activated T lymphocytes require IRF-I. Leukemia I997, I I(SuppI 3):439-440.

52. Horiuchi M, Yamada H, Akishita M, Ito M, Tamura K, Dzau VJ: Interferon regulatory factors regulate interleukin- $I$ beta-converting enzym expression and apoptosis in vascular smooth muscle cells. Hypertension 1999, 33:162-169.

53. Chin YE, Kitagawa M, Kuida K, Flavell RA, Fu XY: Activation of the STAT signaling pathway can cause expression of caspaseand apoptosis. Mol Cell Biol 1997, 1 7:5328-5337.

54. Chen XX, Lai MD, Zhang YL, Huang Q: Less cytotoxicity to combination therapy of 5-fluorouracil and cisplatin than 5-fluorouracil alone in human colon cancer cell lines. World Gastroenterol 2002, 8:84I-846.
55. Eisenhofer G: The role of neuronal and extraneuronal plasma membrane transporters in the inactivation of peripheral catecholamines. Pharmacol Ther 2001, 91:35-62.

\section{Pre-publication history}

The pre-publication history for this paper can be accessed here:

http://www.biomedcentral.com/1471-2407/4/23/prepub
Publish with Bio Med Central and every scientist can read your work free of charge

"BioMed Central will be the most significant development for disseminating the results of biomedical research in our lifetime. "

Sir Paul Nurse, Cancer Research UK

Your research papers will be:

- available free of charge to the entire biomedical community

- peer reviewed and published immediately upon acceptance

- cited in PubMed and archived on PubMed Central

- yours - you keep the copyright
Biolmedcentral 